\title{
Ethnic Tourism: A Case Study of Language and Culture Preservation of the Bateq Indigenous Group of Orang Asli in Peninsular Malaysia
}

\author{
Salasiah Che $\operatorname{Lah}^{1}$ \\ ${ }^{1}$ English Language Studies, School of Humanities, Universiti Sains Malaysia, 11800, Penang, \\ Malaysia
}

\begin{abstract}
Malaysia provides ethnic tourism which is related to the more popularly known as nature or eco-tourism where an indigenous or traditional group of people who live in this environment will interact with and provide services to the tourists who would like to experience ethnic tourism. Ethnic tourism refers to travel motivated by the search for the first hand, authentic and sometimes intimate contact with people whose ethnic and/or cultural background is different from the tourists. Tourists are also driven by the desire to see some of the threatened cultures that may soon disappear through assimilation into the nation's majority. This paper aims to explore ethnic tourism as a preservation strategy for language and culture in a selected community of Bateq Orang Asli group in Peninsular Malaysia in relation the language and cultural preservation of this community. An in-depth interview, a qualitative research technique, was selected as a method of data collection. The multimedia data was also collected including the recordings of the indigenous languages, still pictures and videotapes of the indigenous and cultural activities. The findings of this study show that the Bateq Orang Asli groups have preferences of their languages even though there is a pattern that a high number of lexical items have been borrowed from Malay. Language shift among younger speakers is also becoming a trend. In terms of the preservation of cultural heritage, the Bateq Orang Asli are still very positive about keeping their practices and lifestyles. The involvement of Bateq Orang Asli in promoting ethnic tourism in the surrounding areas near their settlements has contributed to their language and cultural preservation.
\end{abstract}

\section{Introduction}

Malaysia is known as a destination for cultural tourism, ethnic tourism, historical tourism, environmental tourism, and recreational tourism. In the literature on ethnic tourism there has been considerable discussion of what ethnic tourism could offer. Ethnic tourism is marketed to the public in terms of the "quaint" customs of indigenous and often exotic peoples [1]. Destination activities that stimulate tourism include visit to native homes and villages, observation of dances and ceremonies and shopping for primitive wares and curios. Ethnic tourism is "travel motivated by the search for the first hand, authentic and sometimes intimate contact with people whose ethnic and/or cultural background is different from the tourists". Tourists are also driven by the desire to see some of the "threatened" cultures that may soon disappear through assimilation into the nation's majority [2]. Malaysia provides ethnic tourism which is related to the more popularly known as nature or eco- 
tourism where an indigenous or traditional group of people who live in this environment will interact with and provide services to the tourists who would like to experience ethnic tourism. Malaysia has traditional or exotic destinations enough for touristic consumption from the Orang Asli communities such as in Cameron Highlands and Tasik Kenyir in the Peninsular to the Malaysian Borneo of Iban longhouses in the state of Sarawak.

Malaysia is made up of diverse ethnolinguistic minorities. It is made up of three major ethnic groups-Malays, Chinese, and the Indians. The Malays and other Bumiputera groups make up the largest ethnic group of Malaysia (65\%). This is followed by the Chinese $(26 \%)$ and the Indians (7.1\%). In Borneo, the largest indigenous group consists of the Sea Dayaks, or Ibans, followed by the Land Dayaks or Bidayuh while the majority of Sabah's population consists of indigenous peoples, principally Kadazans, Bajaus, and Muruts. In addition to that, there are also many other ethnic groups of Malaysia (1\%) which include the Malaysian Siamese minority, the Portuguese Kristang as well as various indigenous minorities of the Peninsular Malaysia and Borneo. This scenario gives rise to a rich and diverse language, cultural and ethnic identities of Malaysia. However, due to assimilation process, many minority languages, culture and identities are currently at a crisis i.e. many of them are experiencing language and cultural shift phenomenon. Many have assimilated into the mainstream society and consequently lost their identity.

The Negrito or Semang-Negrito (henceforth Semang-Negrito) is the smallest group of Orang Asli sub groups in Peninsular Malaysia. They are the minorities of the minority of indigenous people or Orang Asli of Peninsular Malaysia. They comprise of only three per cent of the Orang Asli population [3]. The Semang-Negrito sub group of Orang Asli are regarded as facing the danger of extinction due to its smallest number of population compared to other sub-groups of Orang Asli [4]. Some subgroups of the population are undergoing drastic transformation of their life due to modernization process which put their language and culture in imminent endangerment.

One of the subgroups of Semang-Negrito Orang Asli of Peninsular Malaysia is the Bateq sub group. Orang Bateq are mainly found the north east of Pahang, North West of Terengganu and south Kelantan. In Pahang, most of them are concentrated in the area of Kuala Tahan particularly the National Park. There are a number of Orang Bateq settlement areas of Kuala Tahan which include: Kampung Kuala Sat, Kuala Kemiang and Kampung Dedari. There is one temporary settlement area in Gua Telinga which is the 'show case' for the tourists visiting the area.

In the state of Terengganu, there are about 766 Orang Asli [5]. There are three major Orang Asli settlements in Terengganu:

(i) Kampung Sungai Pergam, Kemaman

(ii) Kampung Sungai Berua, Kenyir Lake, Hulu Terengganu

(ii) Kampung Sungai Sayap, Besut.

The Orang Asli settlement area of Sungai Berua was established by the JEHOA in 1977. It houses Semoq Beri and Bateq communities. The village is situated in a vast area of oil palm estates which are managed by FELCRA. It was developed in 1993. Of the oil palm estate, 59.73 hectares are in 1993. The village comprises 60 brick houses with zinc roofing for about 339 villagers, a primary school, a kindergarten, a clinic, a 'surau', a community hall, and two houses for government officers [5]. The settlement area is also equipped with water and electricity supplies. The 'Batin' (Village Headman) of the settlement area at the point of study is Rosli bin Desoh. The Orang Bateq in Kampung Sungai Berua have been reported to have been dispersed into smaller group and eventually assimilated with the predominant Semoq Beri Orang Asli community in the settlement area. According to the Village Committee (JKKK) and JAKOA personnel there are about 12 families of Orang Bateq residing at the settlement area of Kampung Sungai Berua. However, there seems to be some problems determining the exact number of Bateq families. One of the main reasons reported by the stationed JAKOA officer was due to identity problem. Many Orang Bateq people who were married to the Semoq Beri identified themselves as the Semoq Beri rather than the Bateq. 
The Orang Bateq of Kampung Sungai Berua have gone through major social and economic changes in their lives as a result of the construction of two new roads. One is the road from Kampung Tapah to the Kenyir Lake via Kampung Sungai Berua where a very high impact economic aquaculture programme undertaken by the state government was being carried out. At the point of the study, there was evidence of new development taking place in the nearby area closer to the lake where a new settlement area was being built to accommodate the participants of the aquaculture project run by the state government. Before the construction of these new roads, it was difficult to gain access to the Orang Bateq community as one had to travel across the mountainous region of Hulu Terengganu and across the Kenyir Lake which took several hours of the journey in order to reach them. With the development of the new road, the Orang Bateq settlement area could easily be reached via the new road from Kampung Tapah to the Kenyir Lake. The settlement area is located just by the roadside of Kampung Tapah to the Kenyir Lake.

The other development that takes place in the region is the road from Kuala Berang to Gua Musang through the lakeside of Kenyir Lake. This has resulted in the frequent interaction with the outsiders such as the government officials, the Chinese taukeys of gaharu and rattan, and the local peddlers, who sell some cooked foods, fish, vegetables and other food items. The development of Kampung Tapah - Kenyir road has made the communities of Semoq Beri and Bateq more accessible [6]. The latter road extended the villagers' activity areas, so that, the villagers could access to other Orang Asli communities in Kelantan easily. The villagers of Kampung Sungai Berua sometimes collected gaharu (agarwood) and fished turtles (tryonyx cartilaginous) with the villagers of Kuala Koh in Kelantan side though fresh water turtle fishing is becoming less popular now as the price is going down drastically. The new road 'acts as a catalyst to some trends in social change that had already begun' [7].

The main economic activities in Kampung Sungai Berua were collecting forest products, such as rattan and gaharu (agarwood), and turtle fishing for sale in the remaining forest surrounding Kenyir Lake. The trekking activities were done by adult male members by using motorbike to reach to the collecting sites. The trekking period before the emergence of Kenyir Lake was on the average of 6.5 days. Now, with the development of the road from Kampung Sungai Berua to Kenyir Lake, the trekking period is much shorter (one day trekking).

With the construction of the new road from Kuala Berang to Gua Musang, villagers could easily gain access to the northern bank of the Kenyir Lake by car instead of motorboat and this has significantly decreased the cost and time. The Orang Bateq normally take their cars or hire vans from the Malays from the nearby villages who take them to the place and bring them back on the fixed date particularly from Kampung Tapah and Kuala Pueh.

The sale of rattan was the most important source of income to the villagers. In 2002 it contributed $55.8 \%$ of the total income. Due to the retreat of Chinese taukeys dwelling in Kuala Berang the sale of rattan has dwindled. Since then the villagers shifted to collecting gaharu (agarwood). Another source of income was turtle fishing and they are normally for sale to Chinese taukeys. As mentioned earlier, this too has dwindled due to lower price of the turtle. Usually, the villagers camped at the spot in the Kenyir Lake area and carried out the activity on a day's trip at the spots. Sometime they extended the spots to the Sungai Koh and the upper Sungai Lebir in Kelantan by car.

The latest major development in the region is the construction of the East Coast Highway which connects to the major roads to Kuala Berang and Gua Musang to the west and Kota Baharu to the north. The highway was scheduled to be completed in 2013. With the opening of the new highway, there would be major development taking place in the region and consequently affect the socio economic aspects of the 'Orang Asli' villagers of Kampung Sungai Berua.

So far, the socio economic development that takes place has major impact on the lives and economy of the Orang Asli communities particularly the Orang Bateq community of Kampung Sungai Berua. The Orang Bateq community is being more mobile and have greater accessibility and exposure to the outside world. The socio economic as well the infrastructure development makes this community accessible by the people who live outside the area, in particular the tourists. Their location which is near Tasik Kenyir has impacted them in relation to tourists' activities. 
The following pictures share the Orang Bateq community's settlement areas and their handicraft products.

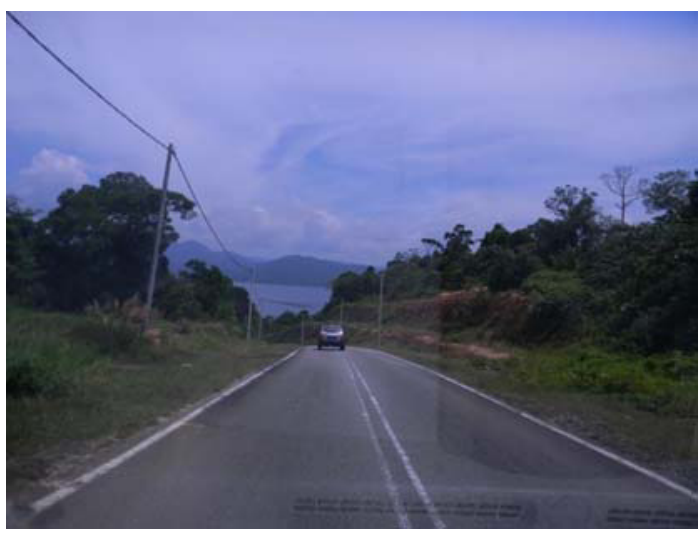

Picture 1: Travelling to the settlement area

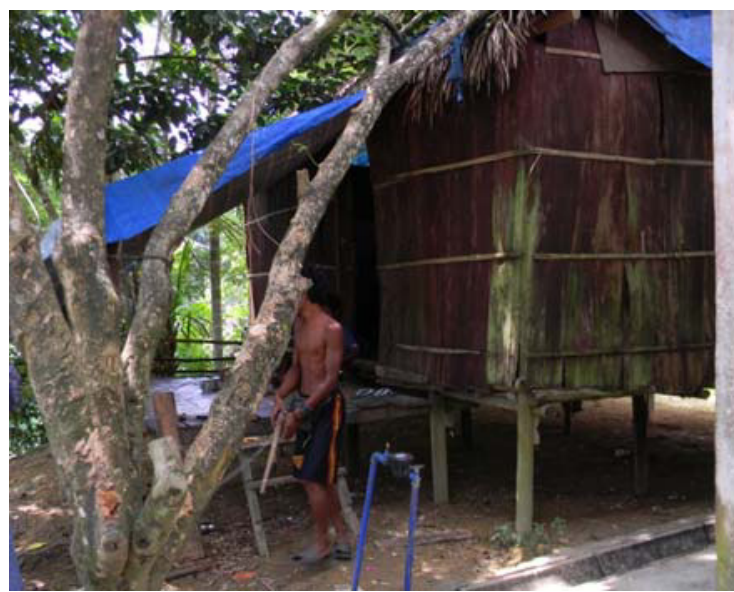

Picture 2: A typical house of Bateq community

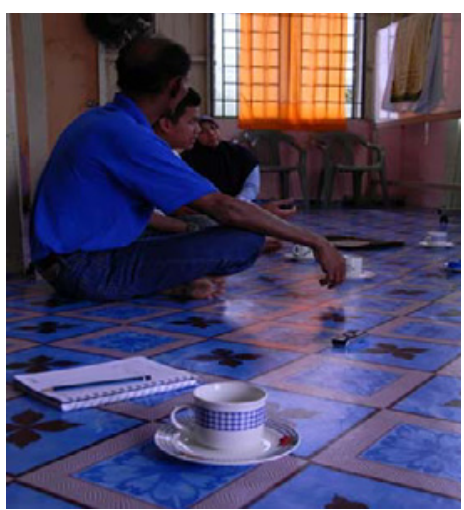

Picture 3: An interview session with one of the respondent

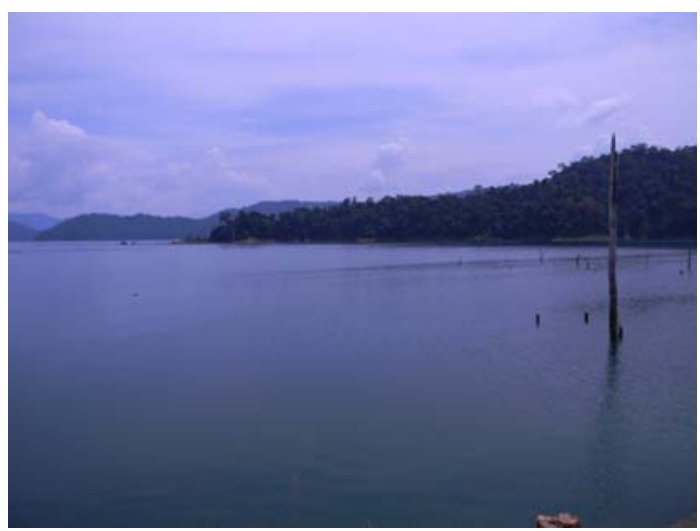

Picture 4: The tourist attraction near the settlement area

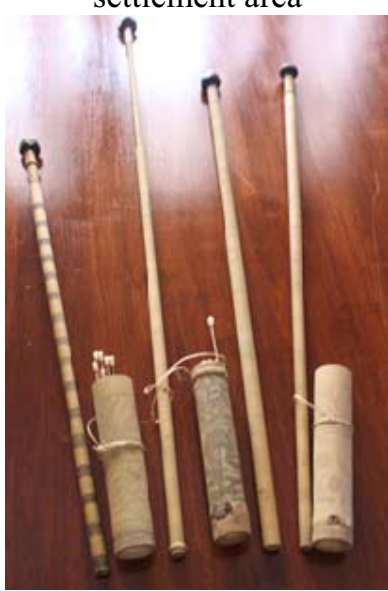

Picture 5: The Bamboo Blowpipes of Bateq community in the National Park

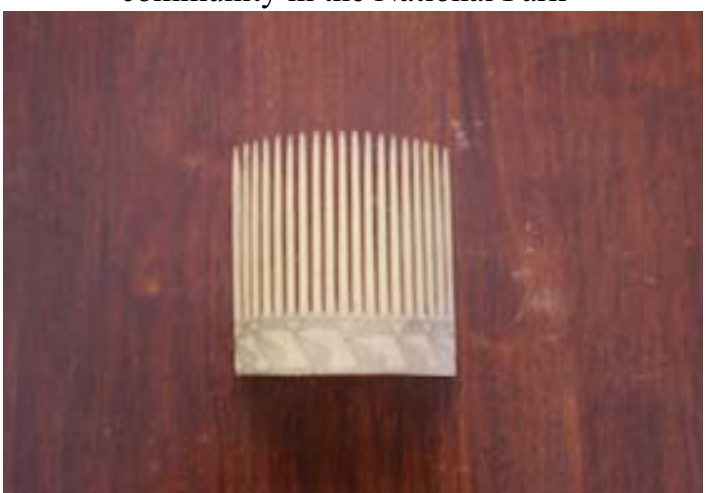

Picture 6: The Traditional Bateq Bamboo Comb 


\section{Methodology}

This paper aims to explore indigenous tourism as a preservation strategy for language and culture in a selected Bateq community of Orang Asli in Peninsular Malaysia. An in-depth interview, a qualitative research technique, was selected as a method of data collection in probing and exploring the speakers' feelings and perspectives on their own ethnic language. The multimedia data was also collected including the indigenous languages, still pictures and videotape of the indigenous and cultural activities. The respondents are from the Orang Bateq communities of Kampung Sungai Berua, Kenyir Lake, Hulu Terengganu and Kampung Sungai Sayap, in the district of Besut, Terengganu. Both the settlements are located in the western interior part of the state of Terengganu.

\section{Findings and Conclusion}

Data were analysed according to themes and the findings are discussed below.

Linguistically speaking, the Orang Bateq of Kampung Sungai Berua still maintains their native language. However, they are very competent multilinguals who constantly interact with their Orang Asli counterparts at the settlement area, the Semoq Beri as well as the local Malays who live in the nearby kampungs. This causes them to constantly shift to those dominant languages. The phenomenon of language shift occurs when a community gives up a language completely in favour of another one [8]. It is further suggests that one of the causes of language shift is the impact of modernization on a previously agricultural or traditional community. This is made worse when there is an existence of the recognized official language which is being adopted as a medium of instruction in the education system.

The Semang-Negrito Bateq children in Kampung Sungai Berua attend schools where the medium of instruction is Malay and the use of Malay in education and other official domains is obligatory. Thus, it is apparent that the Bateq community in this study undergoes both internal and external pressures this leads to the shift of the language to Malay. It should be noted here that the Bateq respondents in this study speak proficient Malay hence facilitating the interview sessions. It is also learnt that many of them can also converse in Semoq Beri language very well. This is due to the fact that the Semoq Beri is the majority group residing at the Kampung Sungai Berua settlement area.

The findings of the study also reveal that there has been extensive borrowing of Malay lexical items which are associated with modern living and technologies. They include the words sekolah (school), pensil (pencil), radio (radio), telefon bimbit (hand phone), bas (bas), doktor (doctor), hospital (hospital). This suggests their ongoing interaction with Malay speakers as their settlement area is in close proximity with the Malay villages.

Cultural wise, it is obvious that the Bateq of Sungai Berua are adopting the Malay culture. This is evident in their changing lifestyle especially their clothing. In general, the Bateq women wear the Malay sarong with a blouse or baju kurung top (Malay baju) and a headscarf (Muslim tudung) while the men wear western-style clothing with long pants. It should be reported here that during one of the visits to the Sungai Berua settlement area, the researchers saw some Bateq children playing the Malay traditional game of sepak takraw as one of their pastime evening activities.

The situation is further aggravated with the conversion of the Bateq to a new religion as they adopt a new life style which is predominantly Malay in nature. This has resulted in not only in language shift but also cultural shift. With their conversion to Islam, they have adopted the Malay culture while those who adhere to their traditional religion still practice their traditional rituals such as sewang rituals. Usually, sewang rituals are normally performed in the nearby forest area. It is usually held at night. It should be noted here that the sewang rituals were said to be influenced by the Semoq Beri community in the settlement area. 
Generally, the Bateq of Kampung Sungai Berua like their Semoq Beri counterparts live in modern concrete zinc roof houses built by the government. However, there are a few of them who refuse to do so. Instead, using their indigenous skills they built their traditional houses using woods and materials gathered from the nearby forest. According to them, traditional houses have much cooling effect compared to the modern houses built in the settlement area.

It is interesting to note that the interior of the traditional Bateq dwelling demonstrates the unique indigenous craftsmanship of the Orang Bateq community. The interior is designed in such a way that it allows free movement of air inside the hut thereby creating the cooling effect to the occupants. There were only a couple of the traditional Bateq huts found at the settlement area of Kampung Sungai Berua. It is afraid that if the skills of building the traditional Bateq houses are not transmitted to the younger generation, it would be a great loss to the unique cultural heritage of the Bateq community of Orang Asli.

\section{Conclusion}

It could be concluded that the Semang-Negrito Bateq group of Orang Asli in the state of Terengganu is threatened with the fate of physical, cultural and language extinction. The SemangNegrito Bateq language and culture are under tremendous pressure of endangerment due to rapid changes and modernization process affecting the community. The Semang-Negrito Bateq in this study are experiencing a demographic crisis due to their dwindling number of population (particularly the Bateq of Kampung Sungai Sayap, Besut) while others have been reported to have been assimilated with other Orang Asli communities e.g. the Semoq Beri (the Bateq community of Kampung Sungai Berua, Kenyir Lake).

The socio economic development that takes place has major impact on the lives and economy of the Orang Bateq communities in Terengganu. This community is becoming more mobile and have greater accessibility and exposure to the outside world. The drastic transformation of their life due to modernization and assimilation processes puts their language and culture in imminent danger of extinction.

Though Orang Asli in general has been very reserve in nature, one venue that plays a vital role in their representation in Malaysia is ethnic tourism. The authorities have put in efforts to bring out the Orang Asli's cultural and identity expressions as they manifest themselves through ethnic tourism in various parts of peninsular Malaysia. Active involvement in tourism has resulted in numerous changes for the Orang Asli economically, socially, culturally, and linguistically.

By demonstrating the diverse ways in which the Orang Asli have been influenced by and through ethnic tourism, including some outcomes generated which benefit them, it is hoped that efforts will continue to emphasize the importance of ethnic tourism both in Orang Asli culture and in the representations of Orang Asli in the Malaysian society today.

\section{References}

1. V.L. Smith, ed, Hosts and Guests: The Anthropology of Tourism 2nd ed. Philadelphia: University of Pennsylvania Press, (1989).

2. Li Yang, Planning for Ethnic Tourism: Case Studies from Xishuangbanna, Yunnan, China, unpublished doctoral thesis at University of Waterloo, Ontario, Canada (2007)

3. Jabatan Hal Ehwal Orang Asli, Data Maklumat Asas JEHOA, Bhg Penyelidikan \& Perancangan, (2004)

4. N. Burenhult, Linguistic Aspects of the Semang. In Reza Rashid \& Wazir Jahan Karim, Minority Cultures of Peninsular Malaysia: Survivals of Indigenous Heritage, AKASS, (2001)

5. Jabatan Hal Ehwal Orang Asli, Data Maklumat Asas JEHOA, Bhg Penyelidikan \& Perancangan, (2009) 
6. K. Suda, A Time Allocation Study on Subsistence Activities of the Bateq in Terengganu. In Orang Asli Negeri Terengganu: Kuala Terengganu: Penerbit Universiti Darul Iman, 71-77 (2007)

7. Hood Salleh and Hassan Mat Nor, Roads are for Development? Some aspects of Jah Hut Social Change. Development Forum 14, 17 - 27 (1984)

8. J.A. Fishman, Reversing language shift: Theoretical and empirical foundations of assistance to threatened languages. Clevedon, UK: Multilingual Matters, (2001) 